\title{
Potentialities of coupling biological processes (biotrickler/biofilter) for the degradation of a mixture of sulphur compounds
}

\author{
Luc Malhautier • Alexandre Soupramanien • \\ Sandrine Bayle • Janick Rocher • Jean-Louis Fanlo
}

\begin{abstract}
This study deals with the potential of biological processes combining a biotrickler and a biofilter to treat a mixture of sulphur-reduced compounds including dimethyl sulphide (DMS), dimethyl disulphide (DMDS) and hydrogen sulphide $\left(\mathrm{H}_{2} \mathrm{~S}\right)$. As a reference, duplicated biofilters were implemented, and operating conditions were similar for all bioprocesses. The first step of this work was to determine the efficiency removal level achieved for each compound of the mixture and in a second step, to assess the longitudinal distribution of biodegradation activities and evaluate the total bacteria, Hyphomicrobium sp. and Thiobacillus thioparus densities along the bed height. A complete removal of hydrogen sulphide is reached at the start of the experiment within the first stage (biotrickler) of the coupling. This study highlighted that the coupling of a biotrickling filter and a biofilter is an interesting way to improve both removal efficiency levels (15-20\% more) and kinetics of recalcitrant sulphur compounds such as DMS and DMDS. The total cell densities remained similar (around $1 \times 10^{10} 16 \mathrm{~S}$ recombinant DNA (rDNA) copies g dry packing material) for duplicated biofilters and the biofilter below the biotrickling filter. The relative abundances of Hyphomicrobium sp. and T. thioparus have been estimated to an average of $10 \pm 7.0$ and $0.23 \pm$ $0.07 \%$, respectively, for all biofilters. Further investigation should allow achieving complete removal of DMS by starting the organic sulphur compound degradation within the first stage and surveying microbial community structure colonizing this complex system.
\end{abstract}

L. Malhautier $(\bowtie) \cdot$ A. Soupramanien $\cdot$ S. Bayle $\cdot$ J. Rocher

J.-L. Fanlo

Ecole des mines d'Alès, 6 Avenue de Clavières, 30319 Alès Cedex, France

e-mail: luc.malhautier@mines-ales.fr
Keywords Volatile sulphur compounds · Biofiltration · Biotrickling filter $\cdot$ Coupling $\cdot$ Hyphomicrobium .

Thiobacillus

\section{Introduction}

Malodorous gases are emitted from industrial biowaste treatment facilities like rendering facilities and wastewater treatment plant. They may induce odour annoyance to the surrounding populations, generate complaints and lead to a lack of acceptance of these facilities. While odorous emissions are not considered to cause health problems directly, they may well be associated with negative health effects, which may cause defensive reactions of people due to psychological effects (Schlegelmilch et al. 2005).

Legislation controlling the emissions of air pollutants (VOC, toxics and odours) has proliferated and became more and more restricted and sets minimum distances from the facility to the nearest housings (Germany, $300 \mathrm{~m}$; France, 200 m; Fanlo 2005; Schlegelmilch et al. 2005).

Field data analysis and literature survey reveal the emission of a large variety of volatile compounds such as oxygenated (volatile fatty acids, ketones, aldehydes and alcohols) nitrogen and sulphur compounds (Van Langenhove et al. 1985). Due to their obnoxious smell and their very low odour thresholds (around $1 \mu \mathrm{g} \mathrm{Nm}^{-3}$ ), especially hydrogen sulphide $\left(\mathrm{H}_{2} \mathrm{~S}\right)$ and organic sulphur compounds such as dimethyl disulphide (DMDS) and dimethyl sulphide (DMS) often cause odour annoyance and deserve special attention (Sercu et al. 2006).

For these reasons, an adequate waste gas management strategy has to be implemented by industrial facilities to control odour emissions (Both 2001; Mahin 2001). Among the gas treatment processes, biotechniques, more particularly biofiltration (Chung et al. 2010; Kennes et al. 2009; Rehman 
et al. 2009) and biotrickling (Arellano-Garcia et al. 2009; Chung et al. 2005), are proving to be efficient, economic and environment-friendly technologies for the treatment of industrial airstreams characterized by high flow rates and low pollutant concentrations. These biotechniques are based on the ability of microorganisms to use volatile pollutants for growth and have been successfully applied for the treatment of gaseous emissions emitted from different industrial processes (Malhautier et al. 2005). Whereas there has been an explosion in the number of papers dealing with biofilters (Iranpour et al. 2005), there has not been nearly as many reports on waste air treatment using biotrickling filters(BTFs) even if the number of full-scale BTFs is rapidly increasing. In the past few 23 years, several successful conversions of full-scale chemical scrubbers to BTF have been demonstrated (Mudliar et al. 2010). Moreover, these bioreactors have been shown to be suitable in several instances when accurate control of the environmental conditions or the degradation of a mixture of complex chemical molecules (Estrada et al. 2011; Hassan and Sorial 2011; Paca et al. 2007; Sempere et al. 2010). However, these biotechnologies are claimed to support low removal efficiencies for the hydrophobic fraction of malodorous emissions, whose elimination is mandatory for efficient odour abatement (Lebrero et al. 2014).

Sulphide-oxidizing bacteria allowing oxidation of sulphide encompass several genera such as Thiobacillus, Acidithiobacillus, Achromatium and Beggiatoa (Ramirez et al. 2009; Tang et al. 2008). It also has been shown that the inoculation of Hyphomicrobium in a biofilter allowed increasing the DMS and DMDS elimination capacity (Smet et al. 1996).

Thus, this study deals with the potential of a combination of two traditional biotechniques (biofiltration and BTF) for the treatment of a mixture of sulphur compounds including DMS, DMDS and $\mathrm{H}_{2} \mathrm{~S}$. So, the aims of this work are, in the first step, to determine the efficiency removal level achieved for each compound of the mixture and, in a second step, to assess the longitudinal distribution of biodegradation activities along the bed height and, finally, to evaluate the total bacteria, Hyphomicrobium sp. and Thiobacillus thioparus densities by using real-time PCR. We focus on Hyphomicrobium and T. thioparus as both genera are well-documented aerobic DMS degraders that have both been identified in biofilters treating volatile organic sulphur compounds through isolation (Cho et al. 1991) and via molecular techniques (Sercu et al. 2006; Hayes et al. 2010).

\section{Material and methods}

Pilot unit

The system consists of two identical and independent biofiltration units (BFA and BFB) and a coupling of biotrickler/biofilter $(\mathrm{BTF} / \mathrm{BF})$. Each biofiltration unit is consisted of PVC columns with an inner diameter of $30 \mathrm{~cm}$ and filled up to $1 \mathrm{~m}$ of bed height, with an alternating of sawmill chips/coconut fibre every $20 \mathrm{~cm}$. The last $20-\mathrm{cm}$ section was filled with pine barks as indicated on Fig. 1. Gas sampling ports are located at the inlet and outlet of the biofilter and along the height of each column every $20 \mathrm{~cm}$ from the inlet up to $100 \mathrm{~cm}$, respectively $(10,30,50,70$ and $90 \mathrm{~cm})$. The biotrickler is consisted of a tank of $300 \mathrm{~L}$ and a PVC column with an inner diameter of $30 \mathrm{~cm}$ and filled with Hiflow rings up to $1 \mathrm{~m}$ of bed height (Fig. 1). Gas sampling ports are located at the inlet and outlet of the biotrickler ( 0 and $100 \mathrm{~cm}$ ).

\section{Packing material}

The physicochemical characteristics of the used packing materials are summarized in Table 1. The mean particle diameter (mm; Sauter diameter) was performed from a granulometric distribution. Each packing material was sifted by using height sieves: 5, 6.3, 8, 10, 12.5, 14, 16 and $20 \mathrm{~mm}$. The maximal water-holding capacity is determined by measuring the weight difference between a known volume of dry and moist packing material previously kept in water for $8 \mathrm{~h}$ and drained. Material porosity is obtained by weighing a known volume of drained packing material, then by covering it with water and weighing again. Determination of $\mathrm{pH}$ was performed from the aqueous suspension after submerging the packing material in water for $1 \mathrm{~h}$ under controlled conditions of temperature $\left(20^{\circ} \mathrm{C}\right)$ and shaking (15 Hz; Vibro-Shaker MM200, Retsch, Haan, Germany).

\section{Inoculation}

For each column, the packing material was seeded with supernatant of wastewater $(10 \mathrm{~L})$ collected at a rendering facility (ATEMAX and SOLEVAL Sud-Est, Viriat, France). The inoculum was recirculated $\left(5 \mathrm{~L} \mathrm{~h}^{-1}\right)$ for $24 \mathrm{~h}$. During inoculation, biofilters were supplied only with air.

\section{Experimental set-up}

The biofiltration units (BFA and BFB) and the coupling (BTF/ $\mathrm{BF})$ were operated in parallel, at ambient temperature, for 3 months (Fig. 1). Each system was supplied with a synthetic gaseous effluent at a velocity of $100 \mathrm{~m} \mathrm{~h}^{-1}$ (EBRT of $36 \mathrm{~s}$ ) in an upward flow mode.

The synthetic gaseous effluent is composed of $\mathrm{H}_{2} \mathrm{~S}$ (Messer France SAS, Puteaux, France), DMS and DMDS (VWR, West Chester, PA) at concentrations of 30, 20 and $20 \mathrm{mg} \mathrm{m}^{-3}$, respectively.

Concerning the BTF, the recirculation of the aqueous phase is of $250 \mathrm{~L} \mathrm{~h}^{-1}$ (water velocity of $3.5 \mathrm{~m} \mathrm{~h}^{-1}$ ), and $\mathrm{pH}$ of the 
Fig. 1 Schema diagram of the pilot unit $(\longrightarrow$ denotes air to be treated)
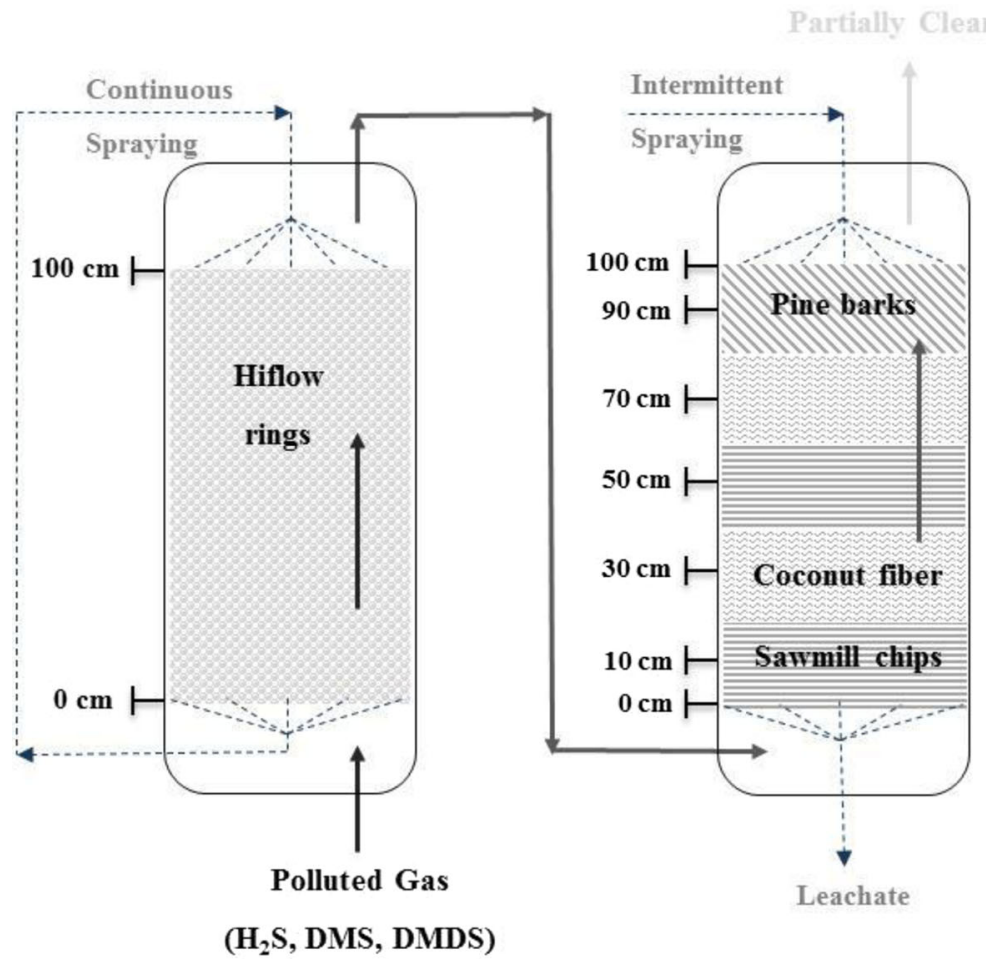

aqueous phase was adjusted at neutrality with a sodium hy-

Percolate waters were collected at the bottom of the column droxide solution $(5 \mathrm{~N})$.

For biofilters, the humidity of packing material was kept by spraying $\left(20 \mathrm{~L} \mathrm{~h}^{-1} \mathrm{~m}^{-3}\right.$ packing material) with a nutrient solution $(\mathrm{pH}=7.5)$ containing $10 \mathrm{mg} \mathrm{L}^{-1}$ of total nitrogen (Optiplan fertilizer, N/P/K of 24/20/2, Duclos International Engrais, Lunel, France). An automated humidification system was carried out. No recirculation of water was operated. The water phase within the bed height was adjusted at neutrality with a sodium hydroxide solution $(5 \mathrm{~N})$ on the basis of daily $\mathrm{pH}$ values of percolate waters.

Daily, gaseous volatile compounds were detected and quantified online by a gas chromatograph (Varian CP-3800, Varian, Palo Alto, CA) equipped with a pulsed flame photometric detector and a 30-m Varian CP-Sil 5 CB for sulphur capillary column $(0.32-\mathrm{mm}$ internal diameter, $0.4-\mu \mathrm{m}$ film thickness). The volatile compound removal efficiency (RE) is calculated to evaluate biodegradation activity of the microbial community. once a week to determine total nitrogen (Nitrogen total reagent set, HACH LANGE, Duesseldorf, Germany), sulphate anion (sulphate reagent SulfaVer ${ }^{\circledR}$ 4, HACH LANGE, Duesseldorf, Germany) and $\mathrm{pH}$.

Bacterial community analysis

\section{DNA extraction}

The procedure for cell dispersion and DNA extraction from biofilter packing material was optimized on the basis of the systemic guideline provided by Cabrol et al. (2010). For all biofilters, at steady state, samples of $5 \mathrm{~g}$ of each packing material were collected, suspended in $15 \mathrm{~mL}$ of sterile physiological saline solution $\left(\mathrm{NaCl} 9 \mathrm{~g} \mathrm{~L}^{-1}\right)$ and shaken by using a Vibro-Shaker MM200 (Retsch, Haan, Germany) at rotating frequency of $10 \mathrm{~Hz}$ for $2 \mathrm{~min}$. After dispersion, each packing material was discarded, and liquid phase containing the

Table 1 Physicochemical characteristics of the used packing materials

\begin{tabular}{lllll}
\hline Packing material & Sawmill chips & Coconut fibre & Pine barks & Hiflow rings \\
\hline Mean diameter (mm) & 11.4 & ND & 10.7 & 21.8 \\
Porosity (\%) & $0.60 \pm 0.02$ & $0.80 \pm 0.03$ & $0.60 \pm 0.02$ & $0.88 \pm 0.01$ \\
Water-holding capacity $\left(\mathrm{m}^{3} \mathrm{H}_{2} \mathrm{O} \mathrm{m}\right.$ & material) & $0.27 \pm 0.03$ & $0.09 \pm 0.04$ & $0.14 \pm 0.04$ \\
$\mathrm{pH}$ & $5.5 \pm 0.4$ & $6.8 \pm 0.2$ & $4.4 \pm 0.2$ & $0.03 \pm 0.01$ \\
\hline
\end{tabular}

$N D$ not determined 
suspended microorganisms was centrifuged at 10,000 rpm for $15 \mathrm{~min}$. The cell pellet was recovered and DNA was extracted using FastDNA ${ }^{\circledR}$ SPIN Kit for Soil (MP Biomedicals, Irvine, CA, USA). Extracted DNA was visualized by gel electrophoresis on $1 \%(w / w)$ agarose gel. DNA quantification was determined by absorbance at $260 \mathrm{~nm}$ using a multiscan spectrum spectrophotometer (Thermo Fisher Scientific, Waltham, MA, USA).

\section{qPCR analysis}

Investigation of the total bacterial Hyphomicrobium sp. and T. thioparus population densities was performed by quantitative PCR (qPCR) targeting the rrs gene. The qPCR reactions were performed according to the protocol described by (i) Gadal-Mawart et al. (2012) using primers V3F (5'-ACTCCC TAGCGGGAGGCAGCAG-3') and V3R (5'-ATTACCGC GGCTGCTGGCAC-3') and (ii) Hayes et al. (2010) using primers hypho F (5'-GGCTCAACCTCGGACT-3') and hypho R (5'-CGAATTTCACCTCTACACTAGGAT-3'), thio F (5'CCTCACGTTATTCGAGCGG-3') and thio R (5'-ACGCAC TCTAGACTGCCA-3'), respectively. The qPCR is realized with a Bio-Rad SsoFast ${ }^{\mathrm{TM}}$ EvaGreen Supermix kit (Bio-Rad, Hercules, CA) and achieved by a thermocycler Rotor-Gene ${ }^{\mathrm{TM}}$ 6000 (Corbett, Mortlake, NSW). In addition to environmental samples, a standard range and a negative control were included. All samples, standard range and negative control were replicat- ed. Efficacy of standards was higher than $90 \%$, and an error rate of less than $2 \%$ was observed for all samples.

\section{Results}

Efficiency levels

The removal profiles are similar for both biofilters as indicated on Fig. 2a, whatever the pollutant, revealing that duplicated biofilters exhibit a highly reproducible functioning. For coupling, complete removal of hydrogen sulphide is reached at the start of the experiment, while, for duplicated biofilters, similar performance is reached after only 8 days of operation. High and stable efficiency level of DMS (70 \%) and DMDS (around $80 \%$ ) was observed for duplicated biofilters. DMS and DMDS efficiency levels are higher for coupling. DMDS was completely removed from day 60, and DMS efficiency level was close to $90 \%$ from day 80 (Fig. 2b). The presence of sulphate in liquid phases highlighted the biological oxidation of volatile sulphur compounds. The conversion rate of gaseous sulphur compounds into sulphate $\left(\mathrm{SO}_{4}\right)$ has been assessed at steady state (from day 65 to day 83) for biofilters BFA and BFB and for coupling $\mathrm{BTF} / \mathrm{BF}$ between gas and liquid phases as follows:

$$
\sum\left(\mathrm{S}-\mathrm{H}_{2} \mathrm{~S}+\mathrm{S}-\mathrm{DMS}+\mathrm{S}-\mathrm{DMDS}\right) g_{\mathrm{i}}=\sum\left(\mathrm{S}-\mathrm{H}_{2} \mathrm{~S}+\mathrm{S}-\mathrm{DMS}+\mathrm{S}-\mathrm{DMDS}\right) g_{\mathrm{f}}+\sum\left(\mathrm{S}-\mathrm{SO}_{4}\right) l_{\mathrm{f}}
$$

where $g$ is gas, $l$ is liquid, $\mathrm{i}$ is the initial day (day 65) and $\mathrm{f}$ is the final day (day 83).

The error mass balance $(e)$ is defined as follows:

$$
e(\%)=\left(\sum \mathrm{S} \text { inlet }-\sum \mathrm{S} \text { outlet }\right) /\left(\sum \mathrm{S} \text { inlet }\right) \times 100
$$

The error mass balance is low and corresponds to 1 , 2.3 and $4.7 / 7.3 \%$ for BFA, BFB and BTF/BF, respectively. These results seem to reveal that the sulphur compounds are mainly oxidized all the way to sulphate which is the end-product of sulphur compound oxidation (Sercu et al. 2006). For DMDS and DMS, the delay needed to reach steady state is of around 60 and 80 days respectively, irrespective of the bioreactor. While the acclimatization phase delay remains important for both duplicated biofilters and coupling, DMS and DMDS removal efficiency kinetics are higher for coupling than those for duplicated biofilters (Fig. 2c, d) from day 16.
Degradation profiles

For duplicated biofilters, the profiles at steady state (Fig. 3) enable to distinguish two groups of contaminants. On the one hand, hydrogen sulphide is very efficiently eliminated: Its complete removal required less than $10 \%$ of bed height (i.e. $10 \mathrm{~cm}$ ). On the second hand, organic sulphur compounds present slower degradation kinetics. The total column height is required to eliminate 65 and $80 \%$ of inlet concentration of DMS and DMDS, respectively.

For coupling, the biofilter is fed with DMS and DMDS only, as $\mathrm{H}_{2} \mathrm{~S}$ is completely removed within the BTF, i.e. $0.85 \mathrm{~m}$ (Fig. 3e). The global behaviour for both organic sulphur compounds remains unchanged. Nevertheless, the DMS and DMDS profiles exhibit a trend shift with an increasing rate of compound degradation. Moreover, DMDS is completely removed and its elimination required $85 \%$ of the bed height. The difference of DMDS and DMS degradation kinetics between duplicated biofilters and the biofilter below the BTF is observed after just over 13 days of operation. 

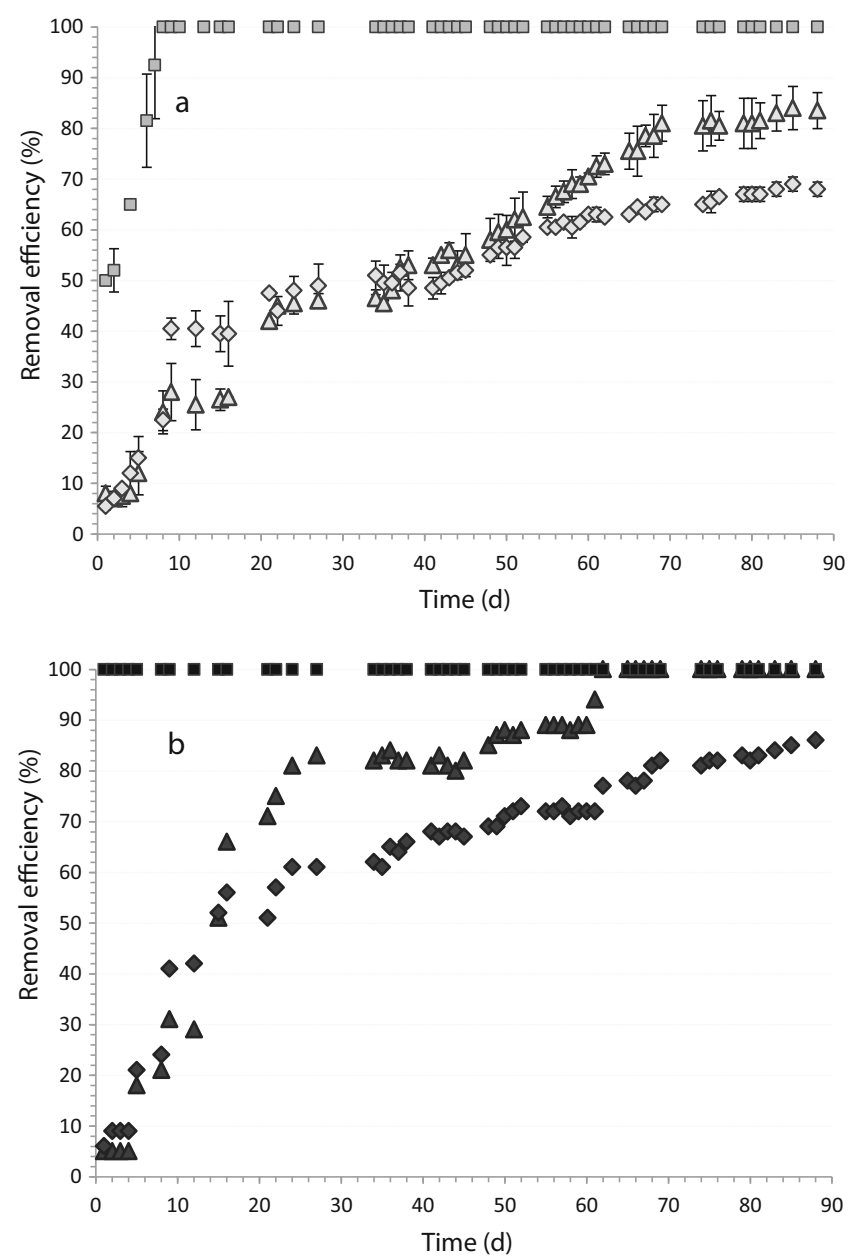

Fig. 2 Removal efficiency levels of $\mathrm{H}_{2} \mathrm{~S}(\square)$, DMS $(\diamond)$ and DMDS $(\Delta)$ for both duplicated biofilters (grey symbols, a) and for biotrickling/ biofilter coupling (dark symbols; b). Comparison of removal efficiency levels of DMDS (c) and DMS (d) for both duplicated biofilters and for

\section{Bacterial densities}

The molecular evaluation of cell densities by qPCR, along the bed height of all biofilters, has been realized from packing material sampled at steady state (day 88 ). The total cell densities ranged between $8 \times 10^{9}$ and $1.5 \times 10^{10} 16 \mathrm{~S}$ recombinant DNA (rDNA) copies g dry packing material for duplicated biofilters and the biofilter below the BTF. No statistical difference was observed for duplicated biofilters (Student's $t$ test $P \gg 0.05)$ and between duplicated biofilters and the biofilter below the BTF (Student's $t$ test $P \gg 0.05$ ).

Cell densities of bacterial populations enabled to degrade DMS and DMDS are also investigated: Hyphomicrobium sp. and $T$. thioparus. For duplicated biofilters, the cell densities are similar (Student $t$ test $P \gg 0.05$ ) around 2.1-2.8 $\times 10^{8}$ and $1.5-2.1 \times 10^{7} 16 \mathrm{~S}$ rDNA copies $g$ dry packing material, respectively. The same trend is also observed between both biofilters and the biofilter below the BTF $\left(3.4 \times 10^{8}\right.$ and $3.2 \times$ $10^{7} 16 \mathrm{~S}$ rDNA copies g dry packing material, respectively)
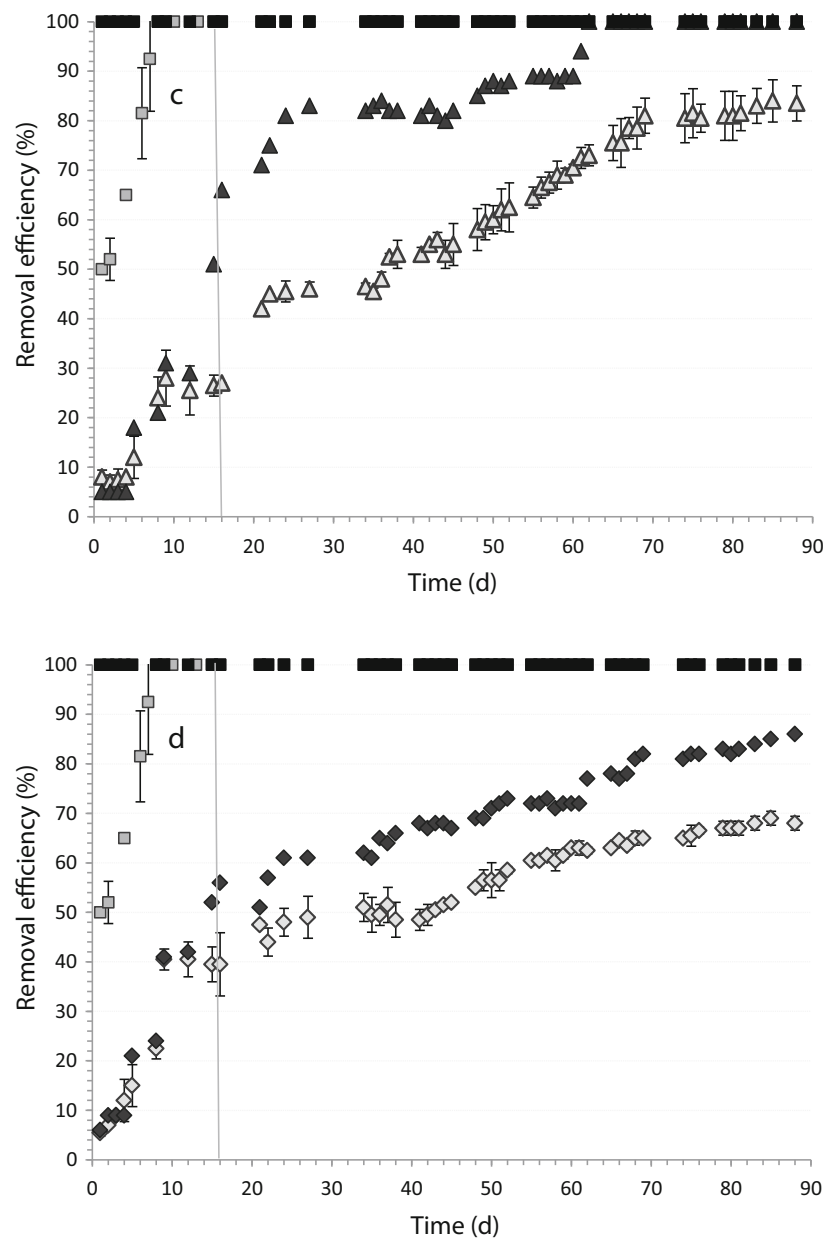

biotrickling/biofilter coupling. Removal efficiency levels of $\mathrm{H}_{2} \mathrm{~S}$ for duplicated biofilters are also mentioned. The vertical line (day 16) indicates the shift of removal efficiency values for $\mathrm{BTF} / \mathrm{BF}$

with no statistical difference (Student's $t$ test $P \gg 0.05$ ). The relative abundances of Hyphomicrobium sp. and T. thioparus have been estimated to an average of $10 \pm 7.0$ and $0.11 \pm$ $0.03 \%$, respectively, for all biofilters. These values have been computed by assuming that two copies of the $16 \mathrm{~S}$ recombinant RNA (rRNA) gene are located in regions of the genome of T. thioparus and that Hyphomicrobium spp. have one 16S rRNA gene copy (Fukushima et al. 2013; Hayes et al. 2010; Beller et al. 2006).

\section{Discussion}

Removal efficiency of sulphur compounds

The results reveal that, for gases containing mixed sulphur compounds, the preference of sulphur-oxidizing bacteria to use hydrogen sulphide as an energy source over tested organic 

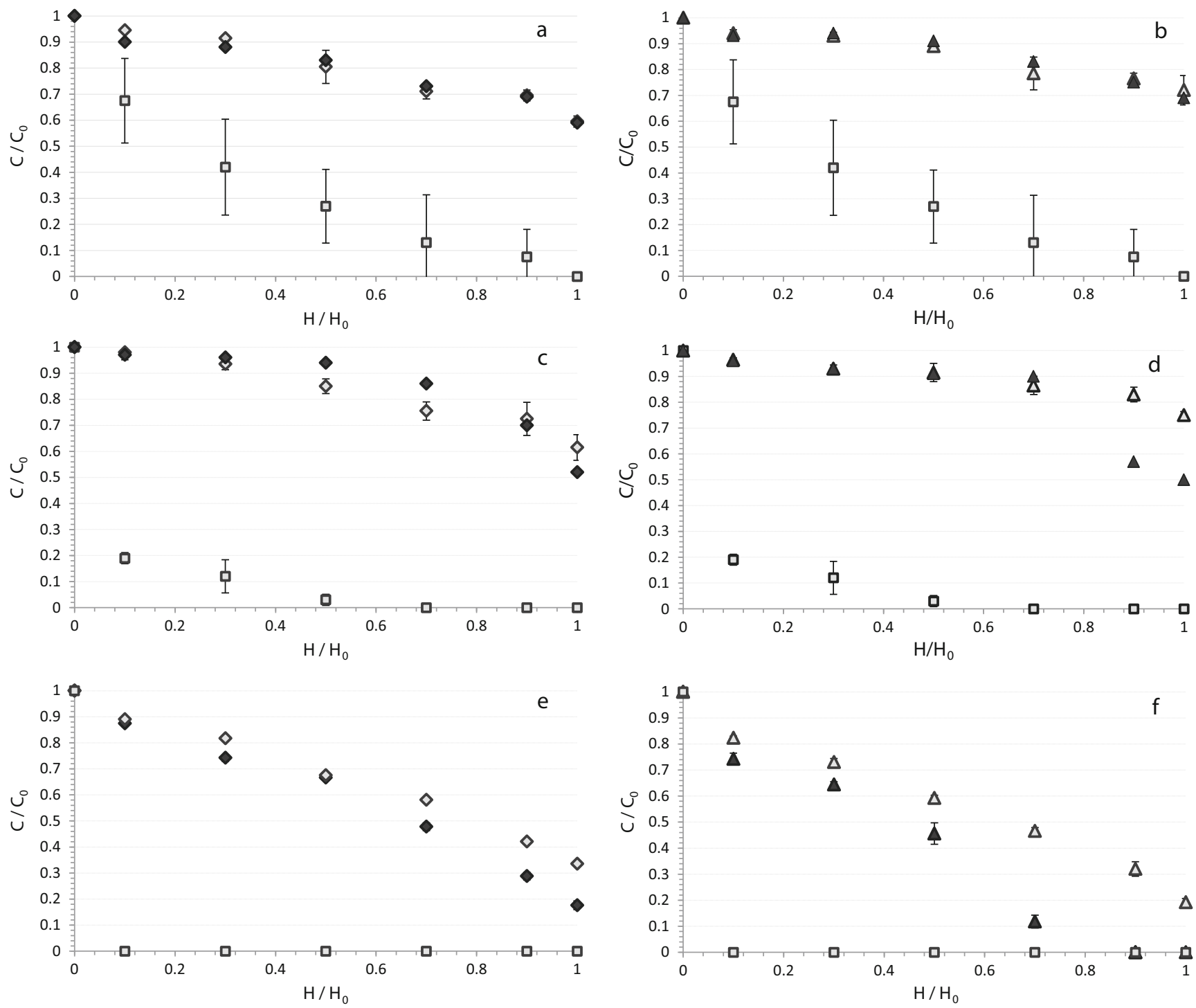

Fig 3 Degradation profiles of $\mathrm{H}_{2} \mathrm{~S}(\square)$, DMS $(\diamond)$ and DMDS $(\Delta)$ for both duplicated biofilters (grey symbols) and for the biofilter combined to biotrickling (dark symbols) at day $9(\mathbf{a}, \mathbf{b})$, day $13(\mathbf{c}, \mathbf{d})$ and steady state (from day 80 to day $88 ; \mathbf{e}, \mathbf{f}) . C$ is the outlet concentration $\left(\mathrm{mg} \mathrm{m}^{-3}\right)$ at the

sulphur compounds promotes low DMS and DMDS consumption (Arellano-Garcia et al. 2009; Caceres et al. 2012; Myung Cha et al. 1999; Ramirez et al. 2011). This result also confirms the higher substrate consumption rate of DMDS compared to that of DMS and seems to highlight that DMS is more recalcitrant than DMDS.

For DMDS and DMS, the delay needed to reach steady state is important, around 60 and 80 days, respectively. This lag phase duration can be attributed to biological factors: substrate availability (poorly soluble compounds) (Chen et al. 2008), biodegradability limitation and/or slow degradation kinetic (Cabrol et al. 2012). Moreover, competitive exclusion phenomena within the bacterial community colonizing the packing material could delay the emergence of functional populations. Moreover, for all bioreactors and at steady

height $H$ of the biofilter (m), $C_{0}$ the inlet concentration $\left(\mathrm{mg} \mathrm{m}^{-3}\right)$, and $H_{0}$ is the total height of the column (m). This biofilter is fed with DMS and DMDS only, as $\mathrm{H}_{2} \mathrm{~S}$ is completely removed within the biotrickling filter. Error bars are indicated

state, as almost all (or all) the bed heights $(90-100 \mathrm{~cm})$ are available for degrading organic sulphur compounds only, it is possible that both substrate availability and slow degradation kinetic mainly affect the removal efficiency of these compounds.

\section{Performances of BTF/BF}

Higher removal efficiencies of DMS and DMDS (15-20\%) are observed by combining BTF and BF. This result can be explained by the spatial distribution of degradation activities: Hydrogen sulphide is completely removed within the first stage (biotrickling) while DMS and DMDS are eliminated within the biofilter only. This spatial distribution could 
prevent inhibition effect of $\mathrm{H}_{2} \mathrm{~S}$ on the bio-oxidation rate of DMS and DMDS.

Moreover, in the case of the biological treatment of a complex mixture of sulphur compounds containing $\mathrm{H}_{2} \mathrm{~S}$ and organic sulphur compounds by using one-stage bioprocess, it is possible that competition between bacterial taxa, through the selection of fitted $\mathrm{H}_{2} \mathrm{~S}$-degrading populations, slows down the development of DMS and DMDS-degrading populations, thus inducing negative effect on performances as it has been revealed in this work (Fig. 3).

Some studies dealing with the use of biological processes in series are scarce. Nevertheless, it has been reported (Ramirez et al. 2011; Ruokojärvi et al. 2001) that the removal efficiency of such compounds is enhanced when two BTFs fed with a mixture stream containing $\mathrm{H}_{2} \mathrm{~S}$, methyl mercaptan, DMS and/or DMDS are combined.

\section{Bacterial densities}

At steady state, the bacterial growth is homogeneous along the bed height, whatever the targeted populations (total bacteria, Hyphomicrobium sp. and T. thioparus). Concerning total bacteria densities, it has been reported that, on a long term, the density of bacterial colonization tends to homogenize along the biofilter height (Grove et al. 2004; Juteau et al. 1999).

The presence of both Hyphomicrobium and Thiobacillus genera is not surprising as both genera have the capacities to metabolize organic sulphur compounds such as DMS and DMDS (Hayes et al. 2010). Nevertheless, the density profiles of both genera exhibited a surprising longitudinal homogeneity in gas biofilters. Almost all (or all) the bed heights (90$100 \mathrm{~cm}$ ) is effectively needed to remove both organic sulphur compounds. The absence of correlation between the physicochemical and microbial spatial distributions can be explained by the environmental standardization along the bed height, arising from (a) the supply of carbon and energy source by the packing material (Friedrich et al. 2003) or/and (b) the percolation of water and nutrients through the packing material in biofilters (Cabrol and Malhautier 2011); as in our study, the flow rate of the nutritive solution is high $\left(20 \mathrm{~L} \mathrm{~h}^{-1} \mathrm{~m}^{-3}\right.$ packing material). It also can be due to the growth of other active populations involved in DMS biodegradation and unidentified in this study.

The results revealed that the bacterial densities of Hyphomicrobium genus are higher $(\times 50)$ than those of T. thioparus. Both genera have been also detected in biological processes treating volatile organic sulphur compounds. Nevertheless, the relative abundances can differ as they have been reported by different authors. Within a BTF-removing DMS (removal efficiency close to $100 \%$ ), the number of copies of 16S rDNA from T. thioparus was several orders of magnitude more abundant than that of $16 \mathrm{~S}$ rDNA from
Hyphomicrobium sp. (Sercu et al. 2006). In return, other works highlighted that 16S rDNA copies of Hyphomicrobium sp. exceeded those of Thiobacillus sp. at the section where the bulk of biodegradation was occurring in biofilters used for the treatment of DMS and methanol (Hayes et al. 2010; Zhang et al. 2006).

To conclude, this study highlighted that the coupling of a BTF and a biofilter is an interesting way to improve both removal efficiency levels and kinetics of recalcitrant sulphur compounds such as DMS and DMDS. The bacterial growth is homogeneous along the bed height, whatever the targeted populations (total bacteria, Hyphomicrobium sp. and T. thioparus). Further investigation should allow (i) achieving complete removal of DMS by starting the organic sulphur compound degradation within the first stage (BFT) and (ii) surveying microbial community structure colonizing this complex system.

Acknowledgments The authors are very thankful to the Orientations Stratégiques des Ecoles des Mines (OSEM) for its financial support.

\section{References}

Arellano-Garcia L, Revah S, Ramirez M, Gomez JM, Cantero D (2009) Dimethyl sulphide degradation using immobilized Thiobacillus thioparus in a biotrickling filter. Environ Technol 30:1273-1279. doi:10.1080/09593330902911713

Beller HR, Chain PSG, Letain TE, Chakicheria A, Larimer FW, Richardson PM, Coleman MA, Wood AP, Kelly DP (2006) The genome sequence of the obligately chemolithoautotrophic, facultatively anaerobic bacterium Thiobacillus denitrificans. J Bacteriol 188:1473-1488. doi:10.1128/JB.188.4.1473-1488.2006

Both R (2001) Directive on odour in ambient air: an established system of odour measurement and odour regulation in Germany. Water Sci Technol 44:119-126

Cabrol L, Malhautier L, Poly F, Lepeuple AS, Fanlo JL (2010) Assessing the bias linked to DNA recovery from biofiltration woodchips for microbial community investigation by fingerprinting. Appl Microbiol Biotechnol 85:779-790. doi:10.1007/s00253-009-22538

Cabrol L, Malhautier L (2011) Integrating microbial ecology in bioprocess understanding: the case of gas biofiltration. Appl Microbiol Biotechnol 90:837-849. doi:10.1007/s00253-011-3191-9

Cabrol L, Malhautier L, Poly F, Lepeuple AS, Fanlo JL (2012) Bacterial dynamics in steady-state biofilters: beyond functional stability. FEMS Microbiol Ecol 79:260-271. doi:10.1111/j.1574-6941.2011. 01213.x

Caceres M, Silva J, Morales M, San Martin R, Aroca G (2012) Kinetics of the bio-oxidation of volatile reduced sulphur compounds in a biotrickling filter. Bioresour Technol 118:243-248. doi:10.1016/j. biortech.2012.04.039

Chen L, Hoff SJ, Koziel JA, Cai L, Zelle B, Sun G (2008) Performance evaluation of a wood-chip based biofilter using solid-phase microextraction and gas chromatography-mass spectroscopyolfactometry. Bioresour Technol 99:7767-7780. doi:10.1016/j. biortech.2008.01.085 
Cho KS, Hirai M, Shoda M (1991) Removal of DMDS by the peat seeded with night soil sludge. J Biosci Bioeng 71:289-291

Chung YC, Cheng CY, Chen TY, Hsu JS, Kui CC (2010) Structure of the bacterial community in a biofilter during dimethyl sulfide (DMS) removal process. Bioresour Technol 100:7176-7179. doi:10.1016/j. biortech.2010.03.131

Chung YC, Lin YY, Tseng CP (2005) Removal of high concentration of $\mathrm{NH} 3$ and coexistent $\mathrm{H} 2 \mathrm{~S}$ by biological activated carbon (BAC) biotrickling filter. Bioresour Technol 96:1812-1820. doi:10.1016/j. biortech.2005.01.003

Estrada JM, Kraakman BNJR, Muñoz R, Lebrero R (2011) A comparative analysis of odour treatment technologies in wastewater treatment plants. Environ Sci Technol 45:1100-1106. doi:10.1021/ es $103478 \mathrm{j}$

Fanlo JL (2005) La réglementation. In: DUNOD (ed) Pollutions olfactives: origine, legislation, analyse, traitement, Paris, France, pp 41-98

Friedrich U, Van Langenhove H, Altendorf K, Lipski A (2003) Microbial community and physicochemical analysis of an industrial waste gas biofilter and design of 16S rRNA-targeting oligonucleotide probes. Environ Microbiol 5:183-201. doi:10.1046/j.1462-2920.2003. 00397.x

Fukushima T, Whang LM, Chen PC, Putri DW, Chang MY, Wu YJ, Lee YC (2013) Linking TFT-LCD wastewater treatment performance to microbial population abundance of Hyphomicrobium and Thiobacillus spp. Bioresour Technol 141:131-137. doi:10.1016/j. biortech.2013.03.122

Gadal-Mawart A, Malhautier L, Renner C, Rocher J, Fanlo JL (2012) Treatment of a gaseous mixture by biofilters filled with an inorganic packing material: performance and influence of inoculation on removal efficiency levels. J Chem Technol Biotechnol 87:824830. doi: $10.1002 /$ jetb. 3718

Grove JA, Kautola H, Javadpour S, Moo-Young M, Anderson WA (2004) Assessment of changes in the microorganism community in a biofilter. Biochem Eng J 18:111-114. doi:10.1016/S1369-703X (03)00182-7

Hassan AA, Sorial GA (2011) Treatment of dynamic mixture of hexane and benzene vapors in a trickle bed air biofilter integrated with cyclic adsorption/desorption beds. Chemosphere 82:521-528. doi: 10.1016/j.chemosphere.2010.10.060

Hayes AC, Zhang Y, Liss SN, Grant Allen D (2010) Linking performance to microbiology in biofilters treating dimethyl sulphide in the presence and absence of methanol. Appl Microbiol Biotechnol 85:11511166. doi:10.1007/s00253-009-2272-5

Iranpour R, Cox HHJ, Deshusses MA, Schroeder ED (2005) Literature review of air pollution control biofilters and biotrickling filters for odor and volatile organic compound removal. Environ Prog Sustain Energy 24:254-267. doi:10.1002/ep.10077

Juteau P, Larocque R, Rho D, LeDuy A (1999) Analysis of the relative abundance of different types of bacteria capable of toluene degradation in a compost biofilter. Appl Microbiol Biotechnol 52:863868

Kennes C, Rene ER, Veiga MC (2009) Bioprocesses for air pollution control. J Chem Technol Biotechnol 84:1419-1436. doi:10.1002/ jctb. 2216

Lebrero R, Gondim AC, Pérez R, García-Encina PA, Muñoz R (2014) Comparative assessment of a biofilter, a biotrickling filter and a hollow fiber membrane bioreactor for odor treatment in wastewater treatment plants. Water Res 49:339-350. doi:10.1016/j.watres.2013. 09.055
Mahin TD (2001) Comparison of different approaches used regulates odours around the world. Water Sci Technol 44:87-102

Malhautier L, Khammar N, Bayle S, Fanlo JL (2005) Biofiltration of volatile organic compounds. Appl Microbiol Biotechnol 68:16-22. doi:10.1007/s00253-005-1960-z

Mudliar S, Giri B, Padoley K, Satpute D, Dixit R, Bhatt P, Pandey R, Juwarkar A, Vaidya A (2010) Bioreactors for treatment of VOCs and odours - a review. J Environ Manage 91:1039-1054. doi:10. 1016/j.jenvman.2010.01.006

Myung Cha J, Suk Cha W, Lee JH (1999) Removal of organo-sulphur odour compounds by Thiobacillus novellus SRM, sulphur-oxidizing microorganisms. Process Biochem 34:659-665

Paca J, Klapkova E, Halecky M, Jones K, Soccol CR (2007) Performance evaluation of a biotrickling filter degrading mixtures of hydrophobic and hydrophilic compounds. Clean Techn Environ Policy 9:69-74. doi:10.1007/s10098-006-0054-7

Ramirez M, Fernández M, Cáceres MS, Pérez RM, Gómez JM, Cantero D (2009) Biotrickling filters for $\mathrm{H}_{2} \mathrm{~S}, \mathrm{MM}$, DMS and DMDS removal by Thiobacillus thioparus and Acidithiobacillus thiooxidans. In: Bartacek J, Kennes C, Lens PNL (eds) Proceedings of the Third International Congress on Biotechniques for Air Pollution Control, Delft, The Netherlands, 28-30 September. CRC Press, London, UK, pp 137-150

Ramirez M, Fernández M, Granada C, Le Borgne S, Gómez JM, Cantero D (2011) Biofiltration of reduced sulphur compounds and community analysis of sulphur-oxidizing bacteria. Bioresour Technol 102: 4047-4053. doi:10.1016/j.biortech.2010.12.018

Rehman ZU, Farooqi IH, Ayub S (2009) Performance of biofilter for the removal of hydrogen sulphide odour. Int J Environ Res Public Health 3:537-544

Ruokojärvi A, Ruuskanen J, Martikainen PJ, Olkkonen M (2001) Oxidation of gas mixtures containing dimethyl sulfide, hydrogen sulfide, and methanethiol using a two-stage biotrickling filter. J Air Waste Manage Assoc 51:11-16. doi:10.1080/10473289.2001.10464260

Schlegelmilch M, Stresse J, Biedermann W, Herold T, Stegmann R (2005) Odour control at biowaste composting facilities. Waste Manage 25:917-927. doi:10.1016/j.wasman.2005.07.011

Sempere F, Martínez-Soria V, Penya-roja JM, Izquierdo M, Palau J, Gabaldón C (2010) Comparison between laboratory and pilot biotrickling filtration of air emissions from painting and wood finishing. J Chem Technol Biotechnol 85:364-370. doi:10.1002/ jctb. 2327

Sercu B, Boon N, Vander Beken S, Verstraete W, Van Langenhove H (2006) Performance and microbial analysis of defined and nondefined inocula for the removal of dimethyl sulfide in a biotrickling filter. Biotechnol Bioeng 96:661-672. doi:10.1002/bit.21059

Smet E, Keymeulen R, Van Langenhove H, Verstraete W (1996) The effect of inoculation and the type of carrier material used on the biofiltration of methyl sulphides. Appl. Microbiol Biotechnol 45: 293-298

Tang K, Baskaran V, Nemati M (2008) Bacteria of the sulphur cycle: an overview of microbiology, biokinetics and their role in petroleum and mining industries. Biochem Eng J 44:73-94. doi:10.1016/j.bej. 2008.12.011

Van Langenhove HV, Roelstraete K, Schamp N, Houtmeyers J (1985) GCMS identification of odorous volatiles in wastewater. Water Res 19:597-603. doi:10.1016/0043-1354(85)90065-X

Zhang Y, Liss SN, Allen DG (2006) The effects of methanol on the biofiltration of dimethyl sulfide in inorganic biofilters. Biotechnol Bioeng 95:734-743. doi:10.1002/bit.21033 